\title{
Ophthalmic Features in SPA-8 with a Homozygous Missense Variant in the Homeobox Domain of the NKX6-2
}

\author{
NKX6-2'nin Homeobox Alanında Homozigot Yanlış Anlamlı Varyantı Olan SPA-8'deki \\ Oftalmik Özellikleri
}

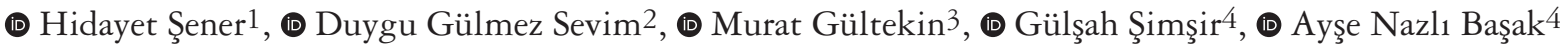

${ }^{1}$ Cukurca State Hospital, Clinic of Ophthalmology, Hakkari, Turkey

2Erciyes University Faculty of Medicine, Department of Ophthalmology, Kayseri, Turkey

3Erciyes University Faculty of Medicine, Department of Neurology, Kayseri, Turkey

${ }^{4}$ Koc University Faculty of Medicine, Department of Biology and Genetics, Istanbul, Turkey

Keywords: Electroretinogram, visual evoked potential, spastic ataxia type 8, NKX6-2 gene mutation

Anahtar Kelimeler: Elektroretinogram, görsel uyarılmış potansiyel, spastik ataksi tip 8, NKX6-2 gen mutasyonu

\section{Dear Editor,}

Spastic ataxia type 8 (SPAX-8) is an inherited autosomal recessive progressive neurodegenerative disorder. This condition typically occurs in adulthood and progresses over the years.

A 22-year-old male was admitted to the neurology clinic with complaints of imbalance, speech disorder, and hand tremor. In the neurological examination, there were dysarthria, dysmetria and dysdiadokinesia, bilateral positive Babinski signs, increased deep tendon reflexes, and ataxic and spastic gait. The patient had mild postural and intentional tremor, and tandem gait and straight-line walking tests were impaired. The muscle strength of proximal and distal lower extremities was $4 / 5$ according to Medical Research Council scale. There was no loss of strength in the upper extremities. Mini mental state examination score was 29 and verbal intelligence score was 100 and performance intelligence score was 86. Magnetic resonance imaging was normal. Blood biochemistry was normal.

Routine anterior segments examination was in normal limits. Central corneal thickness measured by topography system was thinner $(\mathrm{R} / 480 \mu$ and $\mathrm{L} / 473 \mu)$, but endothelial morphology and number of cells were normal on specular microscopy. In fundus examination, it was observed that the cup/disc ratio was increased in the optic disc (0.6). On optical coherence tomography, peripapillary retinal nerve fiber layer thickness was decreased (Figure 1). The amplitudes were low and latencies were prolonged in the pattern visual evoked potentials (VEP) (Figure 2). Electroretinographyrecorded dark-adapted responses' amplitudes were low (Figure 3). In light-adapted responses, the amplitudes were low. The saccades were examined and it was observed that their amplitudes were low and they were slow (Figure 4).

Homozygous p.Ala182Val (c.545C>T) mutation was observed in the NKX6-2 gene with the whole exome sequencing analysis.
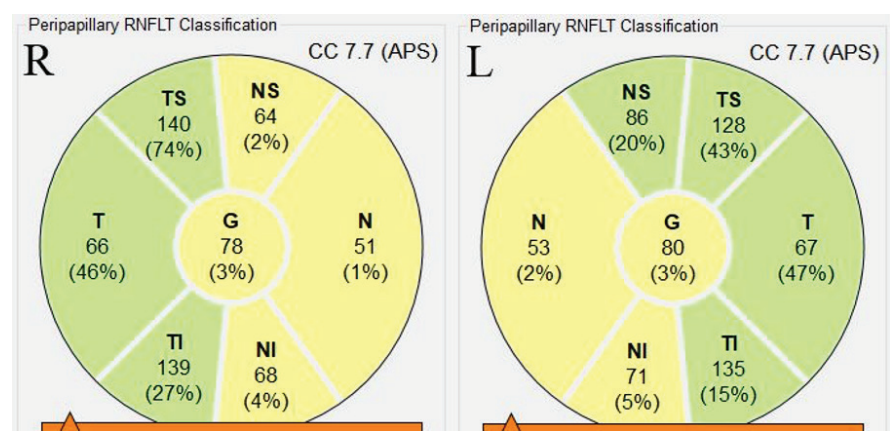

Figure 1. Optical coherence tomography image, $4,1 \mathrm{~mm}$ diameter peripapillary circle, decreased retinal nerve fiber layer (pRNFL) thickness

Address for Correspondence/Yazışma Adresi: Hidayet Şener MD, Cukurca State Hospital, Clinic of Ophthalmology, Hakkari, Turkey Phone: +90 5557196403 E-mail: hidayetsener00@gmail.com ORCID: orcid.org/0000-0001-5836-0170

Received/Gelis Tarihi: 09.12 .2021 Accepted/Kabul Tarihi: 17.01 .2022

${ }^{\circ}$ Copyright 2022 by Turkish Neurological Society

Turkish Journal of Neurology published by Galenos Publishing House. 

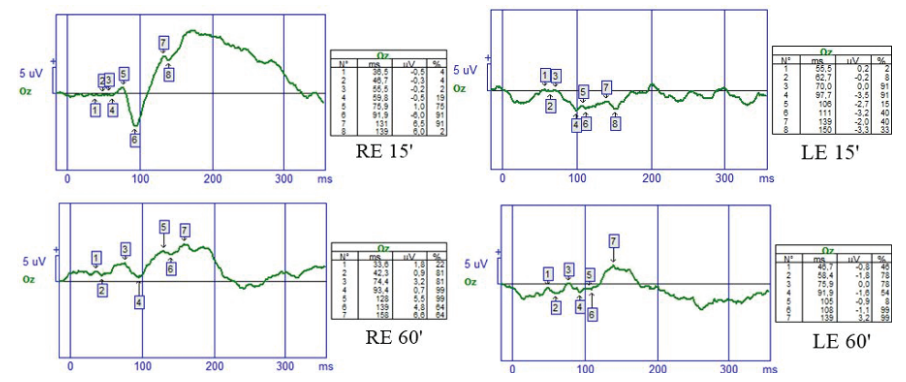

Figure 2. 15 "and 60" model visual evoked potentials test image, decreased amplitudes (P100 wave $\mathrm{R} 15^{\prime} 6,5 \mu \mathrm{V}-60^{\prime} 5,5 \mu \mathrm{V}$ and L 15' faint signal $-60^{\prime} 3,2 \mu \mathrm{V}$ ) and prolonged latency (P100 wave R 15' 131 ms - 60' 139 ms and L 15' faint signal - 60' $139 \mathrm{~ms}$ )

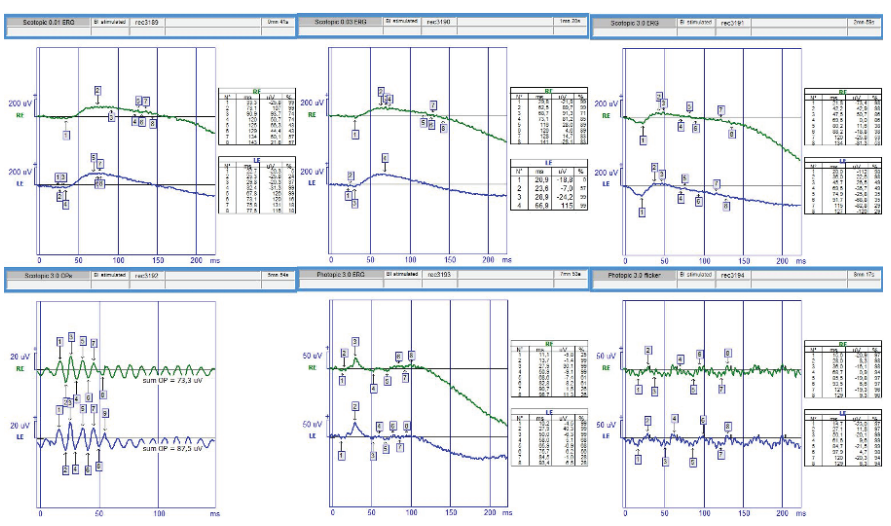

Figure 3. Full-field electroretinography test image, decreased scotopic and photopic amplitudes

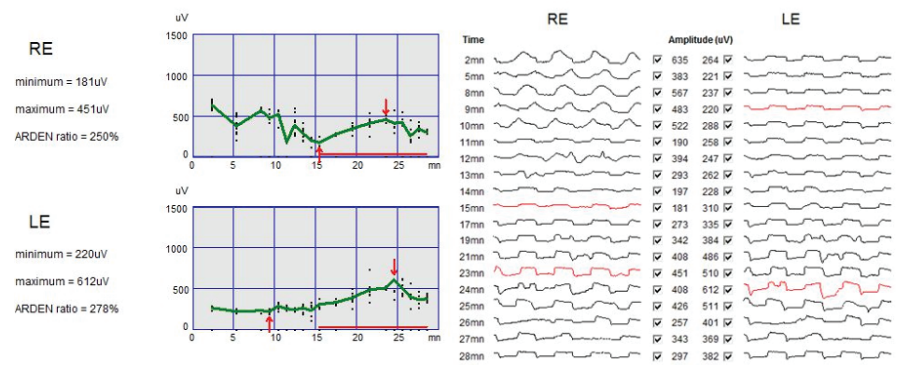

Figure 4. Electrooculography and saccades, Arden ratio within normal limits and saccades with low amplitude

The index individual, his brother, mother, and father were analyzed by using Sanger sequencing. The homozygous status of the index individual was verified. Asymptomatic brother, asymptomatic mother and asymptomatic father were found to be carriers of the same variant.

When the ocular findings of previously reported patients were examined, optic pallor, nystagmus, strabismus, eye movement limitation, hypometric saccad, and visual impairment were reported (1). To our knowledge, only 10 mutations in the NKX62 gene that caused autosomal recessive SPAX-8 were reported. The homozygous p.Ala182Val (c.545C>T) mutation was previously reported in a family in Saudi Arabia. In a patient with the same mutation previously reported, limited eye contact was reported as an ophthalmic finding. Nystagmus, which was a distinctive feature in other reported mutations, was not found in that patient affected by this mutation (2).

The NKX6-2 protein is a transcription factor that acts as a suppressor in the regulation of axon-glial interactions by oligodendrocytes in myelin paranodes (1). Homozygous mutations may impair $N K X 6-2$ function by causing ubiquitin-mediated protein degradation or impairing protein synthesis or affecting the binding of the transcription factor (2). The clinical features associated with $N K X 6-2$ mutations reflect the developmental role of $N K X 6-2$ as a member of the homeobox and direct formation of organs (3). Abnormalities caused by loss of $N K X 6-2$ have been reported not only in the white matter but also in the cranial nerves, including the optic nerve (4).

The features of our patient showed that the features of optic atrophy and decreased VEP responses might be due to the widespread neuronal degeneration, however, the existence of impaired photoreceptor function pointed out to a hyptothesis that the effects of the mutant gene or resultant proteins might have a direct effect on photoreceptors in the retina.

Ethics

Informed Consent: Written consent was obtained.

Peer-review: Externally and internally peer-reviewed.

\section{Authorship Contributions}

Concept: D.G.S., Design: M.G., Data Collection or Processing: H.Ş., Analysis or Interpretation: G.Ş., A.N.B., Literature Search: H.Ş., Writing: H.Ş.

Conflict of Interest: No conflict of interest was declared by the authors.

Financial Disclosure: The authors declared that this study received no financial support.

\section{References}

1. Bereshneh AH, Hosseipour S, Rasoulinezhad MS. Expanding the clinical and neuroimaging features of NKX6-2-related hereditary spastic ataxia type 8. Eur J Med Genet 2020;63:103868.

2. Almatrafi A, Umair M, Eldardear A, et al. A homozygous missense variant in the homeobox domain of the NKX6-2 results in progressive spastic ataxia type 8 associated with lower limb weakness and neurological manifestations. J Gene Med 2020;22:e3196.

3. Chelban V, Alsagob M, Kloth K, et al. Genetic and phenotypic characterization of NKX6-2-related spastic ataxia and hypomyelination. Eur J Neurol 2020;27:334-342.

4. Chelban V, Patel N, Vandrovcova J, et al. Mutations in NKX6-2 cause progressive spastic ataxia and hypomyelination. Am J of Hum Genet 2017;100:969-977. 